\title{
FORECASTING INDONESIAN INFLATION WITHIN AN INFLATION-TARGETING FRAMEWORK: DO LARGE-SCALE MODELS PAY OFF?
}

\author{
Solikin M. Juhro* and Bernard Njindan Iyke** \\ * Bank Indonesia Institute, Bank Indonesia \\ ${ }^{* *}$ Centre for Financial Econometrics, Deakin Business School, Deakin University, Melbourne, \\ Australia. Email: Bernard@deakin.edu.au
}

\begin{abstract}
We examine the usefulness of large-scale inflation forecasting models in Indonesia within an inflation-targeting framework. Using a dynamic model averaging approach to address three issues the policymaker faces when forecasting inflation, namely, parameter, predictor, and model uncertainties, we show that large-scale models have significant payoffs. Our in-sample forecasts suggest that $60 \%$ of 15 exogenous predictors significantly forecast inflation, given a posterior inclusion probability cut-off of approximately $50 \%$. We show that nearly $87 \%$ of the predictors can forecast inflation if we lower the cut-off to approximately $40 \%$. Our out-of-sample forecasts suggest that large-scale inflation forecasting models have substantial forecasting power relative to simple models of inflation persistence at longer horizons.
\end{abstract}

Keywords: Forecasting inflation; Inflation-targeting framework; Large-scale models; Dynamic model averaging.

JEL Classification: E37.

Article history:

Received : : August 01, 2019

Revised : November 16, 2019

Accepted : December 20, 2019

Available online : December 31, 2019

https://doi.org/10.21098/bemp.v22i4.1235 


\section{INTRODUCTION}

We evaluate the performance of an inflation model consisting of a large set of exogenous predictors and lags of inflation against a simple model of inflation persistence for Indonesia within an inflation-targeting framework. The simple inflation persistence model regresses inflation on the first four lags of inflation. Theoretically, several macroeconomic and financial variables can forecast inflation (Sharma, 2019). Accordingly, we follow prior studies (Koop and Korobilis, 2012; Groen, Paap, and Ravazzolo, 2013) and regress inflation on 15 exogenous predictors and four lags of inflation. To estimate these models, we use the dynamic model averaging (DMA) approach developed by Raftery, Kárný, and Ettler (2010). The advantage of this approach is that it allows for time variation of the forecasting model, the predictors, and the parameters in each model.

We evaluate both the in- and out-of-sample forecasting performance of these models. We use posterior inclusion probabilities (PIPs) to determine which predictors can forecast inflation. Predictors with PIPs of approximately 0.50 $(50 \%)$ or higher are considered good predictors of inflation. In the out-of-sample forecast evaluation, we compare the mean squared error (MSE) and log-predictive likelihood difference $(P L D)$ values of the large-scale model to those of the inflation persistence model for out-of-sample forecast horizons $h=1,5$, and 9 months. We set the burn-in to 32 months, such that the forecast evaluation starts in September 1992. The sample period is from January 1990 to June 2018. This covers the inflationtargeting regime and the period immediately before its implementation.

We find that the first lags of inflation, industrial production, import and export prices, global food prices, the global prices of agricultural raw materials, the money supply, the exchange rate between the Indonesian rupiah (IDR) and the US dollar (USD), consumption expenditures, and the unemployment rate are important predictors of inflation. In other words, $60 \%$ of the 15 exogenous predictors can forecast inflation for a PIP cut-off of approximately $50 \%$. This share rises significantly, to nearly $87 \%$, if we lower the cut-off to approximately $40 \%$, since consumer confidence, business confidence, stock exchange capitalization, and crude oil prices can be included in the model. The relevance of these variables, particularly the unemployment rate, consumption expenditures, and confidence indicators, is consistent with the literature (Ang, Bekaert, and Wei, 2007; Stock and Watson, 2008; Groen, Paap, and Ravazzolo, 2013). The large-scale model is more powerful at longer forecast horizons. We find that the simple model of inflation persistence outperforms the large-scale model for an out-of-sample forecast horizon $h=1$ month. However, the large-scale model outperforms the persistence model for out-of-sample forecast horizons of $h=5$ months and $h=9$ months. Koop and Korobilis (2012) and Groen, Paap, and Ravazzolo (2013) find similar evidence, controlling for parameter and model uncertainty, where inflation models with a large set of predictors have greater forecast accuracy relative to naïve or simple models.

Price stability is a core mandate of all central banks. Therefore, the prediction of inflation is always an important goal. The sheer volume of this literature rules out an exhaustive review. Older studies include those of Tzavalis and Wickens (1996), Stock and Watson (1999), Forni, Hallin, Lippi, and Reichlin (2003), and, more recently, Wright (2009), Koop and Korobilis (2012), Faust and Wright (2013), 
and Chen, Turnovsky, and Zivot (2014), and Sharma (2019). These studies all use the Phillips curve (Stock and Watson, 1999) and its extensions to cover a broad range of financial and macroeconomic variables (Sharma, 2019) and estimation strategies (Forni, Hallin, Lippi, and Reichlin, 2003). However, as observed by Koop and Korobilis (2012), common issues affect various inflation forecasts, particularly those based on recursive regression. Structural changes shift model parameters upward or downward (Juhro, Narayan, Iyke, and Trisnanto, 2020). Such shifts, particularly those related to the coefficients, lead to time variation in the underlying relations, which are not well captured by recursive approaches. In addition, a variable's predictive content can change over time, implying that the forecasting model for inflation can also change over time. Moreover, the number of inflation predictors can be large, leading to an even larger number of model combinations to estimate.

We contribute to the general literature by sidestepping these issues and using a DMA approach in forecasting inflation. The DMA approach allows time variation of the forecasting model and the coefficients in each model and accommodates different combination of models and predictors. Another contribution of our study is in response to the skewed focus of prior studies toward developed countries (e.g., Tzavalis and Wickens, 1996; Stock and Watson, 1999; Forni, Hallin, Lippi, and Reichlin, 2003; Stock and Watson, 2003; Wright, 2009; Koop and Korobilis, 2012; Faust and Wright, 2013; Chen, Turnovsky, and Zivot, 2014). Stock and Watson (2003), D'Agostino, Gambetti, and Giannone (2013), and Clark and Ravazzolo (2015), among other, consider the United States, while Caggiano, Kapetanios, and Labhard (2011), Giannone, Lenza, Momferatou, and Onorante (2014), and Berg and Henzel (2015), for example, consider developed European countries.

As noted by Sharma (2019), this is a problem for developing countries' policymakers seeking to understand the evolution of inflation, in pursuit of price stability. Although our study and Sharma's (2019) fill this research gap by developing forecasting models for a developing country, they differ in several ways: Sharma uses a bivariate predictive regression framework, which does not allow for time variation of the forecasting model and the coefficients in each model, nor can it accommodate different combinations of models and predictors. Ramakrishnan and Vamvakidis (2002), who assess the predictors of Indonesian inflation within a multivariate framework, have the same issue. The study closest to ours is that of Mandalinci (2017), who use time-varying parameter and stochastic volatility models to forecast inflation for nine emerging countries, including Indonesia. However, our model has more predictors, uses monthly data, and exploits a computationally efficient estimation strategy.

The Indonesian case is appealing because it is one of the few developing countries to have adopted a clear stance regarding effective policy coordination. The central bank, that is, Bank Indonesia, and the government now coordinate their policy deliberations and formulations (Juhro, Narayan, and Iyke, 2019), which became necessary in the aftermath of the 2007 global financial crisis (Juhro, 2015; Juhro and Goeltom, 2015). Central to this policy coordination is the mandate of achieving price stability under the Bank Indonesia Act of 1999, in growing recognition that both demand-pull and cost-push factors determine Indonesia's inflation, and, consequently, Bank Indonesia's formal implementation 
of the inflation-targeting framework in 2005 (Juhro, 2015; Juhro, Narayan, and Iyke, 2019). Since the early 2000s, the inflation-targeting framework has kept the inflation rate within the target range. There is no denying that a better understanding of the evolution of Indonesian inflation will help policymakers enhance the inflation-targeting framework, especially following recent pressure on the country's exchange rate (Juhro and Iyke, 2019a). In response, our study draws attention to important issues to consider when forecasting inflation within the inflation-targeting framework. We show that, taking into account parameter and model uncertainty, Indonesian inflation forecasting models with large sets of predictors have strong out-of-sample forecasting power relative to simple models, particularly for longer horizons.

Next, Section II presents the inflation forecasting model and the data. Section III presents the results. Section IV concludes the paper.

\section{INFLATION FORECASTING MODEL AND DATA}

\section{A. Inflation Forecasting Model}

The basic building block of all inflation forecasting models is the Phillips (1958) curve, which posits an inverse relation between wages and unemployment and, by extension, an inverse relation between inflation and unemployment (Samuelson and Solow, 1960). The theoretical implication of a negative relation between inflation and unemployment can be stated as

$$
\pi_{t}=\pi_{t}^{e}+\sigma\left(\mu_{t}-\mu_{t}^{n}\right)
$$

where $\pi_{t^{\prime}} \pi_{t}^{e}, \mu_{t^{\prime}} \mu_{t}^{n}$, and $\sigma$ are, respectively, the inflation rate, inflationary expectations, the unemployment rate, the natural rate of unemployment, and the model parameter (Ho and Iyke, 2019).

In practice, it is challenging to measure the natural rate of unemployment and inflationary expectations, because both variables are unobservable. Additionally, bidirectional causality is likely between unemployment and inflation, because they are jointly determined (Ho and Iyke, 2019). Two intuitions help us overcome these estimation challenges. First, the adaptive and rational expectation hypotheses indicate that inflation is persistent, and, second, hysteresis in unemployment indicates that steady-state unemployment is influenced by past actual unemployment (Blanchard and Summers, 1987; Jaeger and Parkinson, 1994; Camarero, Carrion-i-Silvestre, and Tamarit, 2006). Therefore, in application, Equation (1) is reformulated such that inflationary expectations and the natural rate of unemployment are replaced with the lags and/or first differences of inflation and unemployment (King, Stock, and Watson, 1995).

Stock and Watson (1999), among others, have suggested a generalized Phillips curve, which adds several predictors to the basic model. Following these studies, we can write the generalized Phillips curve as

$$
\pi_{t}=\alpha+X_{t-1}^{\prime} \beta+\epsilon_{t}
$$


where $\pi_{t}$ is current inflation; $X_{t-1}^{\prime}$ is a set of predictors, including the first four lags of inflation; $\alpha$ and $\beta$ are model parameters; and $\epsilon_{t}$ is the error term. The benchmark model (inflation persistence model) is Equation (2), but excluding the exogenous predictors of inflation.

Several issues can render forecasts based on Equation (2) inefficient or inaccurate. First, the model's parameters $(\alpha$ and $\beta$ ) can change over time, due to structural changes in the economy, meaning the relations between inflation and its predictors can change over time. Second, the importance of each predictor can change over time, meaning that the forecasting model must change to adapt to this change. Third, there are large number of potential predictors of inflation, leading to an even larger number of model combinations to estimate. Given these issues, the recursive estimation of Equation (2) is less credible.

The DMA approach offers a credible solution to these issues. Let us assume a set of $N$ models $x^{(n)} n=1, \ldots, N$ associated with different subsets of predictors $x_{t}$. Then, the set of models is

$$
\begin{aligned}
& \pi_{t}=x_{t}^{(n)} \theta_{t}^{(n)}+\epsilon_{t}^{(n)} \\
& \theta_{t+1}^{(n)}=\theta_{t}^{(n)}+\gamma_{t}^{(n)}
\end{aligned}
$$

where $\epsilon_{t}^{(n)} \sim N\left(0, H_{t}^{(n)}\right)$ and $\gamma_{t}^{(n)} \sim N\left(0, K_{t}^{(n)}\right)$. Suppose that $M_{t} \in\{1, \ldots, N\}$ indicates the model that is used at each time period, $\Theta_{\mathrm{t}}=\left(\theta_{t}^{(1)^{\prime}}, \ldots, \theta_{t}^{(n)^{\prime}}\right)^{\prime}$ and $\pi^{t}=\left(\pi_{1}, \ldots, \pi_{t}\right)^{\prime}$. Then, the DMA approach entails computing $P\left(M_{t}=n \mid \pi^{t-1}\right) \forall n=1, \ldots, N$ and averaging forecasts across models using these probabilities to forecast inflation at time $t$ using inflation predictors through time t-1 (for details, see Koop and Korobilis, 2012; Catania and Nonejad, 2018).

\section{B. Data}

We follow prior studies (Koop and Korobilis, 2012; Groen, Paap, and Ravazzolo, 2013) to gather the predictors of inflation. Most of the data are from Sharma (2019). Consistent with Sharma's study, our measure of inflation (INF) is the monthly change in the Consumer Price Index. The 15 exogenous predictors are the logarithms of the industrial production index $(L I P)$, the consumer confidence index $(L C C I)$, the business confidence index $(L B C I)$, the global price of food index $(F O O D)$, the global price of agricultural raw material index $(R A W)$, the Jakarta stock exchange capitalization (LCAP), the M2 money supply (LM2), the IDR-USD exchange rate $(L E R)$, crude oil prices $(L O I L)$, net wages $(L N W)$, consumption expenditures $(L C O N)$, and the import price index (IMPPI); the export price index (EXPPI); the interest rate spread (SPREAD); and unemployment (UEM). Our sample period is from January 1990 to June 2018, due to data availability. This period also covers the inflation-targeting framework and, therefore, is more relevant to policymakers in Indonesia. Table 1 provides details on these variables, including their definitions, dates of availability, and sources. 
Table 1.

\section{Definition of Variables}

This table shows the variables, including their definition/construction, and their available dates. Majority of the data comes from Sharma (2019).

\begin{tabular}{|c|c|c|c|}
\hline Variable & Definition & Date & Source \\
\hline INF & Change in consumer price index & 1967M02-2018M06 & Sharma (2019) \\
\hline LIP & Logarithm of industrial production index & 1991M12-2018M04 & Sharma (2019) \\
\hline LCCI & Logarithm of consumer confidence index & 2001M04-2017M12 & Sharma (2019) \\
\hline$L B C I$ & Logarithm of Business confidence index & 2002M03-2017M12 & Sharma (2019) \\
\hline IMPPI & Import price index & 1991M01-2018M05 & Sharma (2019) \\
\hline EXPPI & Export price index & 1991M01-2018M05 & Sharma (2019) \\
\hline FOOD & Logarithm of global price of food index $(2016=100)$. & 1992M01-2019M11 & $\begin{array}{c}\text { Federal } \\
\text { Reserve } \\
\text { Economic } \\
\text { Data }\end{array}$ \\
\hline RAW & $\begin{array}{l}\text { Logarithm of global price of agricultural raw material } \\
\text { index }(2016=100) .\end{array}$ & 1990M01-2019M11 & $\begin{array}{c}\text { Federal } \\
\text { Reserve } \\
\text { Economic } \\
\text { Data }\end{array}$ \\
\hline LCAP & $\begin{array}{l}\text { Logarithm of Jakarta stock exchange capitalization } \\
\text { (value traded, USD). }\end{array}$ & 1990M01-2018M05 & Sharma (2019) \\
\hline LM2 & Logarithm of M2 money supply. & 2003M12-2018M04 & Sharma (2019) \\
\hline$S P R E A D$ & $\begin{array}{l}\text { Difference between one-month JIBOR and three- } \\
\text { month JIBOR. }\end{array}$ & 1991M01-2018M06 & Sharma (2019) \\
\hline LER & Logarithm of Indonesian rupiah per USD. & 1967M02-2018M06 & Sharma (2019) \\
\hline LOIL & $\begin{array}{l}\text { Logarithm of crude oil prices (West Texas } \\
\text { Intermediate USD per barrel). }\end{array}$ & 1986M01-2019M12 & $\begin{array}{c}\text { Federal } \\
\text { Reserve } \\
\text { Economic } \\
\text { Data }\end{array}$ \\
\hline LNW & $\begin{array}{l}\text { Logarithm of average of net wage/salary per month of } \\
\text { employee, interpolated from annual data }\end{array}$ & 1990M01-2018M06 & $\begin{array}{l}\text { National } \\
\text { Labor Force } \\
\text { Survey of } \\
\text { Indonesia }\end{array}$ \\
\hline LCON & $\begin{array}{l}\text { Logarithm of total household consumption } \\
\text { expenditure. }\end{array}$ & 1993M03-2019M03 & $\begin{array}{l}\text { CIEC; Juhro } \\
\text { and Iyke } \\
(2019 b)\end{array}$ \\
\hline UEM & $\begin{array}{l}\text { Unemployment rate, interpolated from semi-annual } \\
\text { data. }\end{array}$ & 1983M01-2019M09 & $\begin{array}{c}\text { Global } \\
\text { Financial } \\
\text { Database }\end{array}$ \\
\hline
\end{tabular}

\section{RESULTS}

\section{A. Summary Statistics}

Table 2 shows the summary statistics of the variables. Our main statistic of interest is the unit root test, since it serves as guidance regarding how the variables should enter into the inflation forecasting model in Equation (2). We employ the widely used augmented Dickey-Fuller (ADF) test. Because the frequency of the data is monthly, we include a maximum of 12 lags in each auxiliary ADF test regression and select the optimal lag using the Akaike information criterion. We report the ADF test statistic alongside the selected optimal lag. The null hypothesis of a unit 
root is rejected for INF, LCCI, $L B C I, S P R E A D$, and $L N W$ at conventional statistical significance levels, implying that these variables are stationary and, therefore, enter into the model as levels. The remaining variables are not stationary and enter into the model as first differences. Note that we verify these results using the test of Narayan and Popp $(2010,2013)$. Table 3 reports the Narayan-Popp test results. Our decision rule is to treat a variable appropriately (i.e., use its difference or leave it as a level) if both tests produce the same outcome, and to difference the variable if the outcomes are split. The Narayan-Popp test results show significant structural breaks in the variables, implying shifts in the parameters of Equation (2).

Table 2.

\section{Summary Statistics}

The table shows summary statistics of the variables. The dependent variable is inflation (INF). The remaining variables are the predictors. Their definitions are in Table 1. SD, JB, and ADF, denote, respectively, standard deviation, $p$-value of the Jarque-Bera statistic, and the Augmented Dickey-Fuller test statistic. We allow a maximum of 12 lags, and include only the intercept term in the ADF test regression. ${ }^{* * *}$, and ${ }^{* * *}$ denote statistical significance at $10 \%, 5 \%$, and $1 \%$, respectively. The sample period is from January 1990 to June 2018.

\begin{tabular}{lcccccc}
\hline Variable & Mean & SD & Skewness & Kurtosis & JB & ADF(Lag) \\
\hline INF & 36.11 & 40.87 & 1.01 & 2.60 & 0.00 & $4.07^{* * *}(8)$ \\
LIP & 12.58 & 0.22 & 0.21 & 2.32 & 0.02 & $-0.81(3)$ \\
LCCI & 4.60 & 0.01 & -1.06 & 4.49 & 0.00 & $-4.07^{* * *}(1)$ \\
LBCI & 4.60 & 0.01 & -1.53 & 4.73 & 0.00 & $-3.61^{* *}(9)$ \\
IMPPI & 0.78 & 0.23 & -0.15 & 2.01 & 0.00 & $-1.28(9)$ \\
EXPPI & 0.77 & 0.22 & 0.36 & 1.85 & 0.00 & $-1.27(2)$ \\
FOOD & 4.43 & 0.24 & 0.29 & 1.70 & 0.00 & $-1.36(1)$ \\
RAW & 4.52 & 0.23 & 0.45 & 2.92 & 0.00 & $-1.89(2)$ \\
LCAP & 11.29 & 1.33 & -0.24 & 2.02 & 0.00 & $-1.98(1)$ \\
LM2 & 14.92 & 0.42 & -0.41 & 2.25 & 0.03 & $-1.78(12)$ \\
SPREAD & -0.18 & 3.51 & -5.61 & 34.61 & 0.00 & $-4.86^{* * *}(0)$ \\
LER & -0.63 & 6.50 & 0.52 & 1.40 & 0.00 & $0.34(12)$ \\
LOIL & 3.55 & 0.66 & 0.31 & 1.71 & 0.00 & $-1.84(1)$ \\
LNW & 13.33 & 1.04 & -0.35 & 1.79 & 0.00 & $-2.86^{*}(12)$ \\
LCON & 13.57 & 0.32 & -0.00 & 2.23 & 0.02 & $-1.37(12)$ \\
UEM & 5.50 & 2.60 & 0.33 & 2.06 & 0.00 & $-1.13(12)$ \\
\hline
\end{tabular}




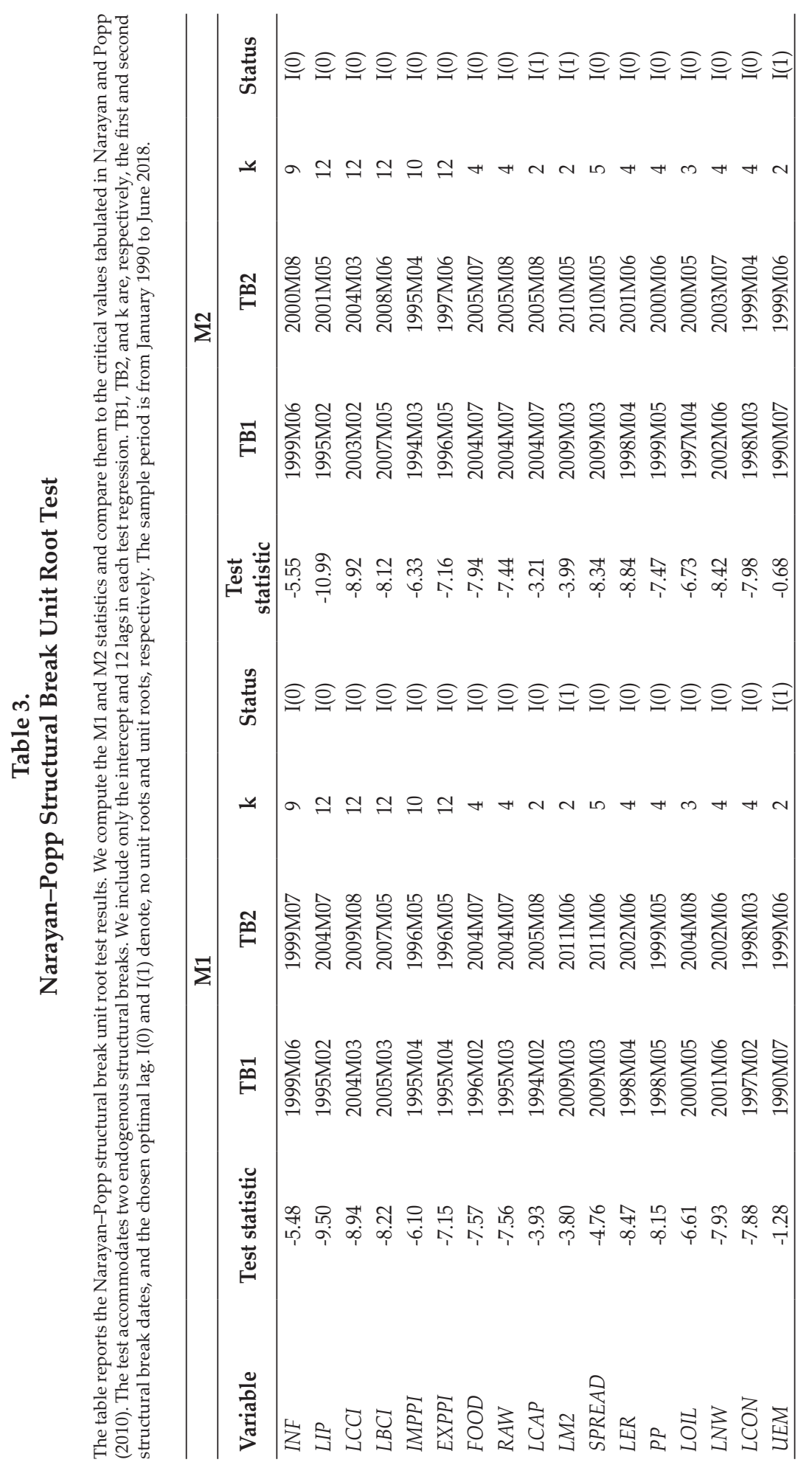




\section{B. In-sample Forecast Evaluation}

Having established how the variables enter into Equation (2), we prepare the model for estimation. Our benchmark model is a simple model of inflation persistence; that is, we regress inflation on the first four lags of inflation. Our generalized model follows prior studies (Koop and Korobilis, 2012; Groen, Paap, and Ravazzolo, 2013) and fits inflation as a function of the above-mentioned 15 exogenous predictors and four lags of inflation. The in-sample forecast evaluation of the generalized model is based on whether the posterior means of the coefficients of these predictors are significant. We use the PIPs of the predictors to determine the significance of the coefficients (or predictors).

Table 4 reports the DMA estimates of Equation (2). Following Iyke (2018), a predictor is said to forecast inflation if its PIP is approximately 0.50 (50\%) or higher. Using this rule of thumb, we find that the first lags of inflation, industrial production, import and export prices, the global food price, the global prices of agricultural raw materials, the money supply, the IDR-USD exchange rate, consumption expenditures, and unemployment significantly forecast inflation. This means that $60 \%$ of the 15 exogenous predictors can forecast inflation when we use a 50\% PIP cut-off, and even a larger share (nearly 87\%) can if we lower the cutoff to approximately $40 \%$. In addition to these predictors, consumer confidence, business confidence, stock exchange capitalization, and crude oil prices can be included in the model if we reduce the PIP cut-off to $40 \%$.

Prior studies (Ang, Bekaert, and Wei, 2007; Stock and Watson, 2008; Groen, Paap, and Ravazzolo, 2013) also find some or all of these predictors forecast inflation. Hence, our results are broadly consistent with the literature. From the Indonesian perspective, Ramakrishnan and Vamvakidis (2002) find the exchange rate and foreign inflation forecast inflation, while Sharma (2019) finds that business confidence, stock market capitalization, and the money supply are important predictors of inflation. Our estimates confirm their findings. We find that unemployment has a positive predictive impact on inflation, implying that high unemployment is followed by high inflation. This result violates the negative relation between inflation and unemployment posited by the Phillips curve. Our study is not the first to document that the relation between inflation and unemployment can be positive. For example, Ho and Iyke (2019) and Hooper, Mishkin, and Sufi (2019) show that the relation can be nonlinear. Specifically, these studies show a threshold beyond which the relation changes from negative to positive.

A number of reasons can explain an upward-sloping Phillips curve. The relation between inflation and unemployment depends on the phase of the business cycle. For instance, King, Stock, and Watson (1995) show that, for the United States, the Phillips curve is unstable and the relation between inflation and unemployment is positive during normal periods and negative during business cycles. The so-called theories of the Phillips curve contend that it is costly for firms to increase output and employment in response to excess demand. Such theories rely on the capacity constraint model and assume both increasing marginal costs and fixed production capacity in the short run. The net result of these short-run rigidities is a convex 
Phillips curve (Dupasquier and Rickets, 1998). ${ }^{1}$ An upward-sloping Phillips curve can also be explained by asymmetries in price adjustment. Stiglitz (1984) and Fisher (1989) use a downward nominal wage rigidity model to demonstrate that workers are more hesitant to accept a drop in their nominal wages compared to a drop in their real wages because of the money illusion. The implication is that excess supply has far less impact on inflation, compared with excess demand, resulting in asymmetries in the inflation-output gap. Gordon (2013) shows that an upward-sloping Phillips curve is the result of supply shocks, which shift the shortrun supply curve. Following the theory of a backward-bending Phillips curve and assuming downward nominal wage rigidity, Palley (2003) shows a trade-off between inflation and unemployment at low inflation rates. This trade-off reverses at high inflation rates. We finding of a positive Phillips curve is consistent with these theoretical arguments.

Table 4.

\section{In-sample Forecasts}

The table reports the in-sample forecasts using the DMA approach. We report the estimated posterior means of the regression coefficients (PMs), posterior inclusion probabilities (PIPs), and their standard deviations (SDs). The constant is always included in the model. A predictor is important if its PIP is approximately 0.50 or more. The sample period is from January 1990 to June 2018.

\begin{tabular}{lcccc}
\hline Variable & PM & SD(PM) & PIP & SD(PIP) \\
\hline Constant & 0.97 & 2.03 & 1.00 & 0.00 \\
$I N F_{t-1}$ & 0.63 & 0.26 & 0.61 & 0.26 \\
$I N F F_{t-2}$ & 0.12 & 0.10 & 0.28 & 0.06 \\
$I N F_{t-3}$ & 0.08 & 0.05 & 0.23 & 0.07 \\
$I N F_{t-4}$ & 0.10 & 0.06 & 0.21 & 0.06 \\
$\Delta L I P_{t-1}$ & 0.03 & 0.07 & 0.50 & 0.00 \\
$\operatorname{LCCI}_{t-1}$ & 0.19 & 0.63 & 0.40 & 0.03 \\
LBCI $_{t-1}$ & 0.18 & 0.62 & 0.40 & 0.03 \\
$\Delta I M P I_{t-1}$ & 0.12 & 0.19 & 0.49 & 0.01 \\
$\Delta E X P P I_{t-1}$ & 0.17 & 0.19 & 0.48 & 0.01 \\
$\Delta F O O D_{t-1}$ & -0.09 & 0.31 & 0.48 & 0.01 \\
$\Delta R A W_{t-1}$ & -0.11 & 0.31 & 0.47 & 0.01 \\
$\Delta L C A P_{t-1}$ & -0.33 & 0.28 & 0.43 & 0.03 \\
$\Delta L M 2_{t-1}$ & 0.37 & 0.37 & 0.49 & 0.00 \\
SPREAD $_{t-1}$ & 0.06 & 0.31 & 0.29 & 0.11 \\
$\Delta L E R_{t-1}$ & 0.16 & 0.18 & 0.48 & 0.01 \\
$\Delta L O I L_{t-1}$ & 0.13 & 0.34 & 0.39 & 0.06 \\
LNW $_{t-1}$ & 0.30 & 0.32 & 0.30 & 0.02 \\
$\Delta$ CON $_{t-1}$ & 0.14 & 0.22 & 0.50 & 0.00 \\
$\Delta U E M_{t-1}$ & 0.12 & 0.30 & 0.46 & 0.04 \\
\hline
\end{tabular}

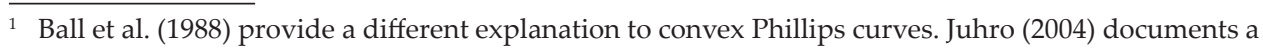
convex Phillips curve for Indonesia. 


\section{Out-of-sample Forecast Evaluation}

We set the burn-in for the out-of-sample forecast evaluation, at 32-months, meaning that the forecast evaluation starts in September 1992. We then compare the MSE and PLD values of the generalized (large-scale) model to those of the inflation persistence model for an out-of-sample forecast horizon of $h=1$ month. Panel A of Table 5 reports the results. The statistics suggest that the simple model of inflation persistence outperforms the large-scale model for an out-of-sample forecast horizon of $h=1$ month. However, is this the case for longer forecast horizons? The results in Panels B and C indicate it is not. The large-scale model outperforms the persistence model for out-of-sample forecast horizons of $h=5$ months and $h=9$ months. This result is consistent with those of Koop and Korobilis (2012) and Groen, Paap, and Ravazzolo (2013), who find that, controlling for parameter and model uncertainty, large-scale inflation models have substantial forecast accuracy relative to naïve or simple models.

Table 5.

\section{Out-of-sample Forecasts}

The table shows the out-of-sample forecast evaluations. We set the burn-in to 32 meaning that the evaluation starts from September 1992. The out-of-sample forecast accuracy measures are mean squared error (MSE) and log-predictive likelihood difference (PLD). We compare the MSE and PLD of the full model to the benchmark over $h=1, h=5$, and $h=9$ month ahead out-of-sample forecast horizons. The sample period is from January 1990 to June 2018.

\begin{tabular}{ccc}
\hline MSE & PLD \\
\hline 2.12 & Panel A: $h=1$ & 134.94 \\
& Panel B: $h=5$ & \\
0.41 & Panel C: $h=9$ & 386.44 \\
& & 524.67 \\
\hline
\end{tabular}

\section{CONCLUSION}

We proposed a large-scale inflation forecasting model for Indonesia. We use a DMA approach to address three issues the policymaker faces when forecasting inflation, namely, parameter, predictor, and model uncertainties. Our in-sample forecasts suggest that the first lags of inflation, industrial production, import and export prices, global food prices, the global prices of agricultural raw materials, the money supply, the IDR-USD exchange rate, consumption expenditures, and the unemployment rate significantly forecast inflation for a $50 \%$ PIP cut-off. If the cut-off is lowered to $40 \%$, we find that consumer confidence, business confidence, stock exchange capitalization, and crude oil prices can also forecast inflation. Outof-sample forecasts suggest that the large-scale inflation forecasting model has substantial forecasting power relative to simple models of inflation persistence at longer horizons. Overall, we document that large-scale models have significant payoffs in terms of inflation forecasting in Indonesia. 


\section{REFERENCES}

Ang, A., Bekaert, G., \& Wei, M. (2007). Do Macro Variables, Asset Markets, or Surveys Forecast Inflation Better?. Journal of Monetary Economics, 54, 1163-1212.

Berg, T. O., \& Henzel, S. R. (2015). Point and Density Forecasts for the Euro Area Using Bayesian VARs. International Journal of Forecasting, 31, 1067-1095.

Ball, L., Mankiw, N. G., Romer, D., Akerlof, G. A., Rose, A., Yellen, J., \& Sims, C. A. (1988). The New Keynesian Economics and the Output-Inflation Trade-Off. Brookings Papers on Economic Activity, 1988, 1-82.

Blanchard, O. J., \& Summers, L. H. (1987). Hysteresis in Unemployment. European Economic Review, 31, 288-295.

Caggiano, G., Kapetanios, G., \& Labhard, V. (2011). Are More Data Always Better For Factor Analysis? Results for the Euro Area, The Six Largest Euro Area Countries and the UK. Journal of Forecasting, 30, 736-752.

Camarero, M., Carrion-i-Silvestre, J. L., \& Tamarit, C. (2006). Testing for Hysteresis In Unemployment in OECD Countries: New Evidence Using Stationarity Panel Tests with Breaks. Oxford Bulletin of Economics and Statistics, 68, 167-182.

Catania, L., \& Nonejad, N. (2018). Dynamic Model Averaging for Practitioners in Economics and Finance: The eDMA Package. Journal of Statistical Software, 84, 1-39. doi:10.18637/jss.v084.i11

Chen, Y. C., Turnovsky, S. J., \& Zivot, E. (2014). Forecasting Inflation Using Commodity Price Aggregates. Journal of Econometrics, 183, 117-134.

Clark, T. E., \& Ravazzolo, F. (2015). Macroeconomic Forecasting Performance Under Alternative Specifications of Time-Varying Volatility. Journal of Applied Econometrics, 30, 551-575.

D’Agostino, A., Gambetti, L., \& Giannone, D. (2013). Macroeconomic Forecasting and Structural Change. Journal of Applied Econometrics, 28, 82-101.

Dupasquier, C., \& Ricketts, N. (1998). Non-Linearities in the Output-Inflation Relationship. Price Stability, Inflation Targets, and Monetary Policy, 14, 131-173.

Faust, J., \& Wright, J. H. (2013). Forecasting Inflation. In Handbook of Economic Forecasting, 2, pp. 2-56. Elsevier.

Fisher, T.C.G. (1989). Efficiency Wages: A Literature Survey. Working Paper 89-5, Bank of Canada.

Forni, M., Hallin, M., Lippi, M., \& Reichlin, L. (2003). Do Financial Variables Help Forecasting Inflation and Real Activity in the Euro Area?. Journal of Monetary Economics, 50, 1243-1255.

Giannone, D., Lenza, M., Momferatou, D., \& Onorante, L. (2014). Short-term Inflation Projections: a Bayesian Vector Autoregressive Approach. International Journal of Forecasting, 30, 635-644.

Gordon, R. J. (2013). The Phillips Curve is Alive and Well: Inflation and the NAIRU during the Slow Recovery. National Bureau of Economic Research (No. w19390)

Groen, J. J., Paap, R., \& Ravazzolo, F. (2013). Real-Time Inflation Forecasting in a Changing World. Journal of Business \& Economic Statistics, 31, 29-44.

Ho, S. Y., \& Iyke, B. N. (2019). Unemployment and Inflation: Evidence of a Nonlinear Philips Curve in the Eurozone. The Journal of Developing Areas, 53. doi:10.1353/jda.2018.0077. 
Hooper, P., Mishkin, F. S., \& Sufi, A. (2019). Prospects for Inflation in a HighPressure Economy: Is the Philips Curve Dead or Is It Just Hibernating? (No. w25792). National Bureau of Economic Research.

Iyke, B. N. (2018). Macro Determinants of the Real Exchange Rate in A Small Open Small Island Economy: Evidence from Mauritius via BMA. Buletin Ekonomi Moneter dan Perbankan, 21, 57-80.

Jaeger, A., \& Parkinson, M. (1994). Some Evidence on Hysteresis in Unemployment Rates. European Economic Review, 38, 329-342.

King, R. G., Stock, J. H., \& Watson, M. W. (1995). Temporal Instability of the Unemployment-Inflation Relationship. Economic Perspectives, 19, 2-13.

Koop, G., \& Korobilis, D. (2012). Forecasting Inflation Using Dynamic Model Averaging. International Economic Review, 53, 867-886.

Juhro, S. M. (2004). Kurva Phillips dan Perubahan Struktural di Indonesia: Keberadaan, Pola Pembentukan Ekspektasi, dan Linieritas. Bulletin of Monetary Economics and Banking, 6, 1-36.

Juhro, S. M. (2015). The Role of the Central Bank in Promoting Sustainable Growth: Perspectives on the Implementation of Flexible ITF in Indonesia. Afro Eurasian Studies, 4, 23-61.

Juhro, S. M., \& Goeltom, M. S. (2015). Monetary policy regime in Indonesia. In Macro-Financial Linkages in the Pacific Region, Akira Kohsaka (Ed.), New York: Routledge.

Juhro, S. M., \& Iyke, B. N. (2019a). Monetary policy and financial conditions in Indonesia. Buletin Ekonomi Moneter dan Perbankan, 21, 283-302.

Juhro, S. M., \& Iyke, B. N. (2019b). Consumer confidence and consumption expenditure in Indonesia. Economic Modelling. https://doi.org/10.1016/j. econmod.2019.11.001

Juhro, S. M., Narayan, P. K., \& Iyke, B. N. (2019). Understanding monetary and fiscal policy rule interactions in Indonesia. Working Paper.

Juhro, S. M., Narayan, P. K., Iyke, B. N., \& Trisnanto, B. (2020). Is there a role for Islamic finance and R\&D in endogenous growth models in the case of Indonesia? Working Paper (Under revision).

Mandalinci, Z. (2017). Forecasting Inflation in Emerging Markets: An Evaluation of Alternative Models. International Journal of Forecasting, 33, 1082-1104.

Narayan, P. K., \& Popp, S. (2010). A New Unit Root Test with Two Structural Breaks in Level and Slope at Unknown Time. Journal of Applied Statistics, 37, 1425-1438.

Narayan, P. K., \& Popp, S. (2013). Size and Power Properties of Structural Break Unit Root Tests. Applied Economics, 45, 721-728.

Palley, T. I. (2003). The Backward-Bending Phillips Curve and the Minimum Unemployment Rate of Inflation: Wage Adjustment with Opportunistic Firms. The Manchester School, 71, 35-50.

Phillips, A. W. (1958). The Relation Between Unemployment and the Rate of Change of Money Wage Rates in the United Kingdom, 1861-1957 1. Economica, 25, 283-299.

Raftery, A. E., Kárný, M., \& Ettler, P. (2010). Online Prediction Under Model Uncertainty via Dynamic Model Averaging: Application to a Cold Rolling Mill. Technometrics, 52, 52-66. 
Ramakrishnan, U., \& Vamvakidis, A. (2002). Forecasting Inflation in Indonesia.

IMF Working paper, No. 02/111.

Samuelson, Paul A.; Solow, Robert M. (1960). "Analytical Aspects of Anti-Inflation Policy". American Economic Review. 50, 177-194.

Sharma, S. S. (2019). Variables Predict Indonesia's Inflation?. Bulletin of Monetary Economics and Banking, 22, 87-102.

Stiglitz, J. E. (1984). Price Rigidities and Market Structure. The American Economic Review, 74, 350-355.

Stock, J. H., \& Watson, M. W. (2008). Phillips Curve Inflation Forecasts (No. w14322). National Bureau of Economic Research.

Stock, J. H., \& Watson, M. W. (1999). Forecasting Inflation. Journal of Monetary Economics, 44, 293-335.

Stock, J. H., \& W Watson, M. (2003). Forecasting Output and Inflation: The Role of Asset Prices. Journal of Economic Literature, 41, 788-829.

Tzavalis, E., \& Wickens, M. R. (1996). Forecasting Inflation from the Term Structure. Journal of Empirical Finance, 3, 103-122.

Wright, J. H. (2009). Forecasting US Inflation by Bayesian Model Averaging. Journal of Forecasting, 28, 131-144. 